\title{
THEORY AND PRACTICE OF STUDYING THE COLLECTION OF SHORT STORIES I. BABEL "KONARMIA" IN EDUCATIONAL PROCESS
}

\author{
Irina Ivanova ${ }^{1 *}$, Olga Evdokimova ${ }^{2}$, Larisa Lyapaeva ${ }^{3}$ \\ Nataliia Obzhogina ${ }^{4}$, Lyudmila Sarbash ${ }^{5}$, Svetlana Fedyay ${ }^{6}$ \\ ${ }^{1}$ Chuvash State University, RUSSIA, leokon2@yandex.ru \\ ${ }^{2}$ Chuvash State University, RUSSIA, evdokimova.ok@mail.ru \\ ${ }^{3}$ Chuvash State University, RUSSIA, lar.lyapaeva@yandex.ru \\ ${ }^{4}$ Sen. Lect., Chuvash State University, RUSSIA, obnatur@gmail.com \\ ${ }^{5}$ Chuvash State University, RUSSIA, sarbash.lu@yandex.ru \\ ${ }^{6}$ Chuvash State University, RUSSIA, sfedyaj09@mail.ru \\ ${ }^{*}$ Corresponding Author
}

\begin{abstract}
The article is devoted to the study of the collection of short stories by I. Babel "Konarmiya", addressed to the events of the distant past-the revolution and the civil war in Russia in 1917-1922. The collection consists of 36 stories, each of which has its own plot and plot basis. The theoretical aspect of studying this literary phenomenon is connected with the need to take into account the super-genre nature of the author's collected collection. The practical aspect is related to the definition of methods and techniques for analyzing the work, determined by the competence approach. The relevance of the research is related to the identification of such structures of the collection, which indicate the artistic unity and integrity of this education. The architectonic discourse allowed us to examine the units of the collection in terms of the role of stories that are in a strong position of the text - the beginning and the end. Analysis of the motivic structure revealed the presence of binary oppositions (life/death, light/darkness, longing/happiness, love/hate),
\end{abstract}

Keywords: Educational process, competencies, methods and techniques, I. Babel, architectonic discourse, motivic structure.

\section{INTODUCTION}

In the educational process of philological orientation a special role is given to the study of works, the genre nature of which is determined by belonging to various forms of cyclic formations. The focus of our attention is the collection of short stories by I. Babel (1894 -1941) "Konarmiya," created from diary entries kept by the future writer when he served as a correspondent in the First Cavalry Army under the pseudonym K. Lyutov. The collection of short stories "Konarmiya" (1925) was supposed to consist of 50 stories, but 36 were published, and the last story "Kiss" was written and included in the collection later. Immediately, Babel's work was at the epicenter of literary disputes: commander C. Budenny, who believed that the writer had distorted reality, could not accept the publication of the collection. The writer was defended by M. Gorky and A. Voronsky, believing that the author has the right to his own look and assessment of events. However, literary scholars today consider Babel's collection of short stories "Konarmiya" a complex and controversial book (Belaya, 1989; Pole, 1986). Characterizing the work of Babel, researchers rightly note the special role of the narrator Lyutov, as well as the principles of mosaic and contrast as leading (Skorospelova, 2007; Bystrova, 2009). The relevance of this article is determined primarily by the fact that the architectonic discourse was 
not the object of the research practice of literary critics. However, it is in it that the main semantic spectra of the interpretation values of works of this type are laid. The goal of the research undertaken is to reveal the role and function of dominant stories that are in a strong position in the composition of the entire education, to identify the motive basis that gravitates to binarity, to reveal the semantic range of architectonic discourse.

\section{METHODOLOGY}

The methodological basis of this article is research of a historical, literary and theoretical nature, studying the features of the formation and functioning of cyclic structures, which include the collection of stories by Babel "Conarmia." The paradigm of this study is determined by comparative and systemic approaches that allow you to update a particular element of the work (motif, symbol, image), revealing its role and place in the structure of the entire collection. These problems are understood on a variety of material in the works of researchers (Gay, 1987; Landor, 1982; Leyderman, 1982).

The most universal understanding of the specifics of the structure of the collection is associated with the isolation of architectonic discourse, which deeply penetrates the author's logic of arranging the stories of the collection in a certain sequence (Landor, 1982; Leiderman, 1982). That is why we turn to his analysis.

Extremely important for this interpretive approach is the appeal to the theory of binarity, according to which all relations within the system are characterized by interaction of opposites. It is in this direction that the thought of J. Lotman moves, believing that "the binary system is deployed into a variety of sets of a polystructural type" (Lotman, 2002).

\section{RESULTS AND DISCUSSION}

Babel's work "Konarmiya" occupies a special place in the literary process of the 20s of the XX century. During this period, there were such works as "Don stories" by M. Sholokhov, "a Dozen knives in the back of the revolution" by A. Averchenko, novels by A. Fadeev "Rout", M. Bulgakov "White guard", stories and novellas by B. Pilnyak, B. Lavrenev, K. Trenev, Vs.Ivanov, and many others that recreate the picture of the civil war in Russia, which was interpreted as a great tragedy (Evdokimova, Ivanova and others, 2020).

Babel in his creative quest tended to create collections ("Konarmiya", "Odessa stories", "The story of my dovecote") and short stories. the collection "Konarmiya" is addressed not only to the creation of sociohistorical reality, but also to the ethical side, which appears in the works of subtext. The collection combines the tragic and the ironic, the scary and the funny, the cruel and the compassionate. Babel showed the contradictions of the era, revealed man as an element that is captured by revenge, cruelty, indifference, hatred, arising from the realization of the power of power.

The story that opens the collection ("Crossing the Zbruch"), and the final story ("Kiss») they form a kind of unity, the so-called ring, saturated with leitmotives of various levels. It is these motives that will unfold in other stories of "Konarmiya". Both stories are based on the motive of chance, but it is in the last story that chance becomes fateful for the characters who begin to dream of the future, of a new life and of happiness.

For the story "Crossing the Zbruch" binary motives are important - life/death, parents/children, light/darkness, sun/moon, beauty/ugliness. The final story "the Kiss" is characterized by a repetition of the same motives, although the plot - plot basis, eventfulness are of a different nature, and the story itself is not so tragic. In the first story, the characters ("I") stop at a house for the night. In the final story ("Kiss») the hero also stops for the night at a school teacher, meets members of his family - his daughter-widow Tomilina Elizabeth Alekseevna and grandson Misha. But the main thing in this story is the motive of the nascent feeling of love, happiness, and joy. However, the ending of the story is open, and there is a lot of heavy, doomed: the hero goes into the night and catches up with his own, the old father dies in his sleep, but the daughter does not know about it yet. She stays with her son, hoping for the return of her beloved.

However, the ending of the story is open, and there is a lot of heavy, doomed: the hero goes into the night and catches up with his own, the old father dies in his sleep, but the daughter does not know about it yet. She stays with her son, hoping for the return of her beloved.

The role of these stories in shaping the overall meaning of the collection is important: they set the overall tone of perception. Both stories are characterized by the chronotope of the path, which permeates the entire collection, turning into a leitmotif, and thus unites such diverse plot material into a single whole. But there is a subtext plan related to the chronotope of the path: it is about finding the way to a "good revolution", as the hero of the story "Gedali" reflects: "You shoot because you are a revolution. And revolution is a pleasure. And pleasure does not like in an orphan house. A good man does good things. Revolution is a good thing for good people. But good people don't kill....where is the sweet revolution? " (Babel, 1986, p. 21). So in the stories there is a philosophical plan, switching events in the perspective of reflection, rhetorical questions 
that already contain the answer.

The motives of light and darkness in the stories are revealed not only as properties of the natural cosmos, but also as concepts of indirect assessment of events, actions of heroes, who most often demonstrate the "simplest skill" to kill a person. It is in this case that the darkness seems to approach and becomes thicker and thicker, covering the entire person. These are the most hopeless stories of the collection - "Letter", "The Doctrine of the wheelbarrow", "Clothespin", "Squadron Trunov".

The motives of life and death appear in one of their variations as "living-dead", these principles are not so much opposed as brought together. In the story "Crossing the Zbruch", a dead old man and a living red army man sleep in the same bed, one sleeping forever, the other screams, jumps up, pushes him in his sleep, as if continuing the day's chase. Note that the epithet "dead" describes the life of peaceful people in the era of war: dead flowers, a dead butterfly are the only details that remain in the looted shop of Gedali. But the main thing in this story is the daughter's words about her father: "Where else on the whole earth will you find such a father as my father..." (Babel,1986, p.5). It strikes her that at the time of her death, her father thought about her and asked the poles not to kill in front of her daughter. And this power of parental love is more shocking than the fear and horror of life, this power is able to revive and bring a person back to life. The image of the father becomes symbolic, suppressing all other images of the story. The energy of perception of events and their author's assessment are laid down in these framing stories that echo each other. They are the structural centers in the collection, to which all the others are drawn in one way or another. This is emphasized in the system of architectonic discourse by the fact that almost every story occasionally contains imagesarchetypes of father, mother, children, light, and darkness. The image of the mother is associated with eternity and is revealed in the story "Rabbi". Gedali composes an authentic hymn to the mother: "Everything is mortal. Eternal life is reserved only for the mother. And when the mother is dead, she leaves behind a memory that no one has yet dared to desecrate. The memory of our mother feeds us with compassion, as the ocean, the immeasurable ocean feeds the rivers that cut through the universe" (Babel, 1986, p. 24).

The motif of beauty, harmony as an antinomy to momentary evil-war, death-is realized through unique pictures of the natural cosmos, scattered in most stories: "fields of purple poppy", "yellowing rye"," thickets of hops"," orange sun","majestic moon". "playing the wind" ("Crossing the Zbruch river"). But the description of nature also has a deadly beginning: "the orange sun rolls across the sky like a severed head", sometimes not just "night silence" is recorded, but a state where everything is "killed by silence", there is "death of the Bazaar" (Babel,1986,p.4-5.20). As a result, we see that life is suppressed by death, it is everywhere and in everything. In the following stories, each of the motifs appears as a development of those embedded in these ring works. This is how the collection's stories interact with the framing works.

The motif of light is multidimensional and is realized as a dream of a different life in the absolute majority of the collection's stories. The Central story is "the Sun of Italy", where the hero only wants to go, where he has never been. But Italy is a symbol of light. The luminous principle is also connected with another cosmic image that appears in the midst of darkness - the moon. The moon reflects not only the life of the cosmos, but is also endowed with the qualities of a living being, opoetized, reflects the inferiority and distortion of human life, loneliness: "the moon wanders", "the homeless moon wandered around the city", "the moon hung over the courtyard like a cheap earring"," the misty moon wandered along the road like a beggar " (Babel,1986,p.72; Ivanova, 2012,p. 117). The General unhappiness of life, the destruction of the foundations of life (homelessness) are transmitted through these motives.

The motives of longing and boredom convey the spiritual, internal distortion of a person, switching the events of real life to an existential plan. The motives that mark the value of being and return a person to the true life (love, happiness, joy) are given an insignificant place, and these are not religious motives in the collection "konarmiya". Religious feelings are trampled upon, violated, nothing sacred remains in people's souls, as evidenced by destroyed and looted churches, churches, temples, synagogues, murdered priests and priests ("at St. Valens", "pan Apolek", "Gedali", "Rabbi"). It is a sense of longing that permeates the entire story "Squadron Trunov", in which the image of the main character is ambivalent: he is both a hero who saves the squadron by calling fire on himself, and a cruel killer who violates the order prohibiting the execution of prisoners. Lyutov, who makes out the prisoners (there were 10 of them), refuses to" wash out " one at the request of Trunov. Trunov kills two people with special cruelty and for no reason, first an old man ("took him with a saber"), then a young man from a Japanese carbine. However, Trunov forbids Andryushka eight-Yearold to engage in looting, who immediately pulls off the dead old man's trousers, selects two more uniforms from the pile and drives off, not responding to the order, until Trunov shoots. Trunov and Vosmiletov are killed in an unequal battle with American airplanes: "... the tapes released by ours did not cause them any harm" (Babel, 1986, p. 65). Internally, Trunov is aware of his guilt, so he rushes to death, prepares for it (writes a letter about the appointment of Semyon Golov to the post of commander instead of himself), dies, 
and is buried "as a "world hero" "in a public garden, in a flower garden,in the middle of the city" (Babel,1986, p. 65). Trunov's Death is a kind of form of remorse, atonement for his cruelty.

\section{CONCLUSION}

It is the architectonic discourse that gives the collection its internal unity. The collection's conceptual ideas are extracted from stories that have leitmotivs at all levels. These include ring stories ("Crossing the Zbruch", "Kiss") and stories rich in concrete and metaphorical episodes that switch events to a timeless plan. The architectonics of the collection are determined by the deployment of those motives that are set by the framing stories. Architectonic discourse is aimed at reflecting the contradictions of the era, the complexity and ambiguity of the tragic path of man.

\section{REFERENCE LIST}

Babel, I. E. (1986). Konarmiya. Stories. Elista. 220 p.

Belaya, G. A. (1989). Don Quixotes of the 20s: "the Pass" and the fate of his ideas. Moscow. P. 149 -169.

Bystrova, O. N. (2009). I. E. Babel. Russian literature of the XX-beginning of the XXI century. In 2 TT. T. I. Under edited by L.P. Krementsov .Moscow.P.173

Gay, N. K. (1989). Pushkin's prose: the poetics of narration. Moscow. 284 p.

Ivanova, N. A. (2012). The lunar code in B. Zaitsev's story "Calmness". Philology, art history and cultural studies: current issues. Materials of the international correspondence scientific and practical conferences. Novosibirsk. P. 116-119.

Landor, M. (1982). Big prose - from small. About one emerging genre in the twentieth century. Questions literatues. No. 8. P. 75-107.

Leiderman, N. L. (1982). The movement of time and the laws of the genre. Sverdlovsk. 1982. 256 p.

Lotman, Y. M. (2002). History and typology of Russian culture. St. Petersburg, Russia. P. 67 - 70.

Olga Evdokimova, Irina K. Ivanova, Larisa Lyapaeva, Nataliia Obzhogina, Lyudmila Sarbash,

Svetlana Fedyay. The Concept of "War" in Russian Literature of the Twentieth Century // INTCESS 2020: 7th International Conference on Education and Social Sciences: Abstracts \& Proceedings (20-22 January 2020, Dubai, U.A.E.). - Dubai, 2020 - Pp. 275-282. - URL: https://www.ocerints.org/intcess20_epublication/abstracts/a95.html.

Polek, L. M. (1986). I. Babel. I. Babel. Cavalry. Stories. Elista. P. $210-211$.

Skorospelova, E.B. (2007). Literature of the Revolution, 20 "s - early 30" s: Ways of Developing Prose. History of Russian literature. XX century. In the 2nd part of Ch.1.Pod edited by V.V. Agenosov. Moscow. P.390. 